\title{
IMPLIKASI PSIKO-SOSIO-RELIGIUS TRADISI NYADRAN WARGA KEDUNG OMBO ZAMAN ORDE BARU (Tinjauan Filsafat Sejarah Pragmatis)
}

\author{
Hasyim Hasanah \\ UIN Walisongo Semarang \\ hasyimhasanah_82@yahoo.co.id
}

\begin{abstract}
Abstrak
Nyadran merupakan salah satu bentuk ritual sosial keagamaan masyarakat (khususnya) Jawa, biasa dilakukan menjelang bulan Ramadhan. Nyadran sebagai sebuah peristiwa sejarah yang menjadi tradisi, memiliki makna filosofis yang sangat beragam bagi masing-masing komunitas warga masyarakat. Variasi pemaknaan nyadran tergantung dari mana orang memahaminya. Makalah ini bertujuan untuk menganalisis implikasi psiko-sosio-religius tradisi nyadran warga Kedung Ombo zaman Orde Baru dalam tinjauan filsafat sejarah pragmatis. Penggunaan filsafat sejarah pragmatis berupaya menggali nilai-nilai moral sejarah yang meliputi perubahan, perkembangan, dan kemajuan nilai moral peristiwa sejarah. Untuk mendapatkan gambaran menyeluruh, maka penulis mempergunakan metode induktif. Data diperoleh melalui wawancara, dan dokumentasi. Analisis data menggunakan kerangka kerja filsafat sejarah pragmatis. Hasil penelitian menunjukkan bahwa, a) Praktik nyadran warga Kedung Ombo baru dilakukan pada masa orde baru tahun 1987, sebagai reaksi atas pembangunan Waduk Kedung Ombo; b) Nyadran bagi warga sekitar Waduk Kedung Ombo memiliki implikasi psikologis berupa respon emosional positif dalam bentuk penerimaan, kesadaran, dan semangat bertahan hidup menghadapi bencana kelaparan; c) Implikasi sosiologis tradisi nyadran memunculkan rasa solidaritas sosial sebagai wujud penghormatan kepada para leluhur; d) implikasi religius merupakan ungkapan rasa syukur atas karunia Tuhan.
\end{abstract}

Keywords: Nyadran, filsafat sejarah pragmatis, implikasi psiko-sosio-religius 


\section{A. Pendahuluan}

Kegiatan ritual memungkinkan para pesertanya dari berbagai komitmen emosional menjadi perekat bagi kebersamaan mereka, dan juga sebagai bentuk pengabdian kepada kelompok. Kehadiran sebuah ritual merupakan efek dari hubungan sosial yang pada umumnya terjadi perubahan sikap, pendekatan, dan tingkah laku publik sesuai dengan yang diharapkan oleh masyarakat (Wijaya, 1993:87). Lambang atau simbol yang terdapat pada suatu tradisi digunakan untuk menunjukkan makna filosofis atau nilai-nilai moral dan dakwah dibalik setiap penampilannya. Simbol-simbol menghubungkan orang satu dengan yang lainnya, dan mengandung unsur-unsur kejiwaan yang mendalam (Effendi, 2009:138). Bentuk tradisi yang memiliki nilai sejarah luar biasa adalah nyadran.

Nyadran telah berlangsung sejak zaman dahulu. Nyadran diambil dari kata Sadra, yang memiliki arti ziarah kubur. Nyadran merupakan salah satu tradisi tahunan yang memiliki nilai istimewa bagi masyarakat Jawa. Nyadran dilakukan secara turun temurun sebagai agenda tahunan menjelang bulan Ramadhan, bulan yang dianggap suci dan sakral. Peralatan ritual dan ubo rampe nyadran memiliki keunikan tersendiri. Nyadran awalnya dilakukan masyarakat jawa sebagai ekspresi pemujaan roh leluhur, dan setelah kehadiran Walisongo di Jawa, maka ritual pemujaan roh telah ditransformasikan ke dalam nilai-nilai budaya yang islami (Hasanah, 2013).

Ritual nyadran di setiap daerah memiliki kekhasan sendiri-sendiri. Salah satunya di Kedungrejo Kecamatan Kemusu Boyolali. Momen sejarah menunjukkan bahwa nyadran di Kedungrejo Kemusu, menjadi ritual baru, di saat warga masyarakatnya berada dalam kondisi tertekan. Tekanan ini muncul sebagai akibat warga menghadapi bencana pembanguanan Waduk Kedung Ombo pada masa pemerintahan Orde Baru. Masyarakat pada saat itu berada dalam suasana ketakutan, keputus-asaan, dan ketidakberdayaan akibat kebijakan pemerintah untuk mendirikan Waduk Kedung Ombo. Sejak tahun 1981 hingga 1988 warga Kedung Ombo berada dalam kondisi memprihatinkan, hidup dalam keterpaksaan dan serba kekurangan. Ganti rugi yang dijanjikan akan diberikan, ternyata tidak sesuai dengan harapan. Pada saat bencana kelaparan melanda, di situlah ritual nyadran terbentuk. Melalui bantuan dari Mangkunegaran Solo dan mbah Mangun, warga masyarakat bangkit, dan selanjutnya mengekspresikan semangat hidupnya kembali, melalui doa bersama, yang ditujukan untuk memohon perlindungan, sebagai ekspresi syukur kepada Tuhan, dan media mendoakan para leluhur.

Tradisi nyadran pada saat itu (era tahun 80-90 an) berbeda dengan pelaksanaan nyadran saat ini. Terdapat pergeseran nilai dan bentuk ritual nyadran. Pergeseran nilai dan bentuk inilah yang memberikan implikasi berbeda pada perayaan nyadran di Kedungrejo Kemusu Boyolali. Mendasarkan hal tersebut maka, penulis berupaya ingin mengkaji lebih dalam mengenai historisitas nyadran di Kedungrejo Kemusu Boyolali. Penulis akan berupaya menggunakan kerangka kerja filsafat sejarah pragmatis dalam menganalisis ritual nyadran di Kedungrejo Kemusu Boyolali, sehingga nilai peristiwa sejarah ini dapat dijadikan pedoman, acuan, moral bagi kehidupan masyarakatnya untuk kehidupan selanjutnya, kehidupan masa depan. 


\section{B. Konsep Dasar Filsafat Sejarah Pragmatis}

Filsafat sejarah berupaya memahami hakekat sejarah sedalam-dalamnya (Bakker dan Zubair, 1990:20). Filsafat sejarah berdasarkan objek formanya dibedakan menjadi 3 (tiga), filsafat sejarah spekulatif memandang sejarah sebagai peristiwa (res gestae), filsafat sejarah kritis memandang sejarah sebagai kisah atau ilmu (rerum gestarum), dan filsafat sejarah pragmatis memandang sejarah sebagai sistem nilai (value) (Ankersmit, 1987:16-17). Filsafat sejarah yang akan digunakan dalam makalah ini adalah filsafat sejarah pragmatis.

Filsafat sejarah pragmatis ${ }^{1}$ berusaha merenungkan dan menjelaskan alasan-alasan praktis atau kegunaan mempelajari sejarah masa lalu, nilai-nilai (value) yang terkandung dalam peristiwa sejarah yang dapat menjadi inspirasi, motivasi, asas ataupun pedoman bagi kehidupan praktis sehari-hari, dan konsep kehidupan masa yang akan datang. Tradisi telah menunjukkan pentingnya sejarah dalam pengajaran moral (instruction moral). Ritter (1986:322) menjelaskan bahwa filsafat sejarah pragmatis berupaya menggali nilai-nilai moral sejarah dipandang dalam filsafat moral. Daliman (2014:81) menyebutkan filsafat sejarah pragmatis sebagai suatu paham yang hendak menggunkan sejarah sebagai tauladan atau contoh dalam bertindak dan berbuat, sejarah sebagai cerminan kehidupan. Filsafat sejarah pragmatis menyarankan agar nilai-nilai sejarah (the value of history) lebih dikaitkan pada hal-hal yang bersifat umum, seperti pengetahuan sosial diri (social-self-knowledge), kepuasan intelektual dan emosional (intellectual and emotional satisfaction), dan dimensi temporal pada kesadaran diri sendiri dari manusia (temporal dimension to man's awareness of himself).

Filsafat sejarah pragmatis memiliki objek material sejarah sebagai nilai, yaitu nilainilai yang terkandung dalam peristiwa sejarah. Objek formalnya adalah nilai-nilai, ajaranajaran, pandangan praktis kehidupan. Nilai-nilai itu selanjutnya dapat dijadikan sumber pengajaran moral (moral instruction) atau dasar filsafat moral (moral philosophy). Filsafat moral membicarakan pertimbangan-pertimbangan tentang tindakan dalam hubungan antar manusia (Wilujeng, 2012). Alasan mendasar mengapa manusia sejarah memiliki pertimbangan moral sebagai landasan segala perilaku, karena manusia memiliki akal dan kesadaran (awareness) (Departemen Pendidikan dan Kebudayaan, 1985:31). Dimensi moral bukanlah suatu konsep tersendiri, namun menyangkut penghayatan pada masing-masing bidang yaitu fisiko-kimis (pelican); dunia hidup (bios), dunia psikis (naluri, nafsu, emosi), dan dunia human (Van Laer, 1962:136; Bakker, 1990:28).

Machiavelli (1969-1527) dalam Bakker (2001:39) menyebutkan bahwa nilai kegunaan sejarah sampai abad ke 18 berdasarkan teori tauladan sejarah (the exemplar theory) yang dapat digunakan sebagai bahan pengajaran moral. Sejarah dapat mengajarkan kepada manusia bagaimana harus bersikap, mengambil keputusan, dan bertindak. Filsafat sejarah adalah historia vitae magistra yang berarti sejarah adalah guru kehidupan, mengajarkan dan mendidik persoalan yang boleh dilakukan dan persoalan yang tidak boleh dilakukan berdasarkan sumber nilai yang ada.

1 Paham ini dipelopori oleh ahli retorika Yunani terutama Socrates, yang banyak dipengaruhi sejarawan Thucydides. Menurut Socrates, sejarah masa lalu akan memberikan kita contoh-contoh atau teladan yang ada pada sejarah masa lalu. 
Terdapat empat hal dalam mempelajari filsafat sejarah pragmatis yaitu pertama mengilhami pengambilan sikap, perbuatan, dan pengambilan keputusan. Menilik peristiwa masa lalu berarti melihat khasanah kenangan atas perjuangan, kepahlawanan, pengalaman, kegagalan, dan lain sebagainya. Kenang-kenangan tersebut dapat membangkitkan gairah dan memberikan inspirasi dalam mewarisi, mempertahankan, meneruskan, dan mengambil bagian dalam karya, citacita, dan gerakan para pendahulunya. Kedua, sebagai pesona perlawatan, artinya mengajak manusia berwisata ke masa lalu, sehingga dapat merenggutkan dari kebosanan, kepenatan, dan memberikan kesenangan estetis karena bentuk dan susunan serta bahasanya yang serasi dan indah. Ketiga, memberikan pelajaran dan pengalaman kehidupan. Keempat, mengajarkan orang bersikan arif, bijaksana, adil, dalam bertindak dengan penuh pertimbangan. Baccon menyebutkan bahwa historia make men wish, vitae magistra, aspek fundamental pendidikan untuk mengembangkan sikap-sikap jiwa dan semangat (attitudes of mind) penuh pertimbangan (Daliman, 2014:84-86). Sejarah dalam kajian filsafat merupakan pengetahuan moral, bukanlan pengetahuan empirik. ${ }^{2}$ Filsafat sejarah tidak dapat dipisahkan dari persoalan moral. Persoalan moral selalu berupaya untuk dapat mengungkapkan sistem nilai, pertimbangan mengenai cara berpikir dan bertingkah laku sesuai dengan yang seharusnya, dan bersumber pada suara hati (conscience) (Maritain, 2005:62). Perhatian dari sejarawan seperti Collingwood menyebutkan bahwa subject-matter filsafat sejarah secara umum mengandung relevansi jenis emosi tertentu dari aksi manusia.

Collingwood dalam penyelidikan realitas sejarah adalah memperkirakan semua aksi kejiwaan manusia ke dalam kegiatan penyadaran sejarah (Collingwood, 1956:xxxv). Pembahasan moral yang ada pada filsafat sejarah setidaknya menggambarkan relasi tradisi masyarakat yang mengandung sistem nilai, aturan, moral dan etik dalam mengetahui perjalanan secarah dengan baik (Collingwood, 1956:57). Collingword menyebutkan bahwa bertindak untuk suatu motif tertentu, melibatkan sistem nilai yang dapat dijadikan acuan untuk pengajaran moral.

Pengajaran moral tidak hanya sekedar melangsungkan spesies, tetapi bagaimana ia dapat bertanggung jawab terhadap diri sendiri, keluarga, masyarakat bangsa/Negara dan kemanusiaan secara umum. Tuntuntan tanggung jawab ini adalah perbuatan yang bernilai. Perbuatan yang bernilai itulah yang menjadikan kehidupan manusia menjadi bermakna. Kebermaknaan hidup manusiai memiliki kekuatan moral dibutuhkan untuk mengendalikan akal dan nafsu, dan selanjutnya akan mengarahkan setiap perilaku kearah pedoman hidup yang diyakininya benar. Lebiih lanjut dijelaskan bahwa manusia adalah makhluk berbudaya, merupakan resultante dari hakekat manusia sebagai animal sociale, animal rasionale, dan makhluk yang bermoral. Dalam hubungan ini, tradisi telah menunjukkan peranan penting sejarah sebagai bentuk pengajaran moral, dan karenanya dipandang sebagai filsafat moral serta menjadi sumberr pendidikan dan pengajaran (Daliman, 2014:12).

2 Pengetahuan moral adalah mempelajari kenyataan yang seharusnya (should to be) ada di dunia, sedangkan pengetahuan empirik adalah mempelajari kenyataan-kenyataan yang ada di dunia. Pengetahuan moral bertalian dengan tindakan atau perbuatan yang harus dipertanggungjawabkan, sedangkan pengetahuan empirik bertalian dengan dunia nyata (Maritain, 2005:10, dalam http://www.nd.edu/Departments/Maritain/etext/philhist.html. 


\section{Konsep Dasar Nyadran Masyarakat Jawa}

Nyadran atau sadranan merupakan ungkapan refleksi sosial-keagamaan pada suatu komunitas masyarakat tertentu. Ritus ini dipahami sebagai bentuk pelestarian warisan tradisi dan budaya nenek moyang. Pelaksanaan nyadran masih kental dengan tradisi ritual HinduBudha, animis-dinamisme yang diakulturasikan dengan nilai-nilai Islam. Nyadran adalah ritual tahunan yang dilakukan oleh masyarakat Jawa. Tradisi nyadran menurut Prasetyo (2010:2) dikenal dengan sadranan adalah tradisi yang dilakukan oleh orang jawa setiap menjelang puasa Ramadhan, yang dilakukan di bulan Sya'ban (kalender Hijriyah) atau Ruwah (kalender Jawa) untuk mengucapkan rasa syukur yang dilakukan secara kolektif dengan mengunjungi makam atau kuburan leluhur yang ada di suatu kelurahan atau desa.

Rohman (2010) yang menyebutkan nyadran sebagai proses membersihkan hati. Pengertian nyadran dalam pemahaman ini didasarkan pada asal kata nyadran "sodrun, sadran, sudra" yang berarti dada atau hati, berkumpul dengan orang awam dalam situasi sama. Purwadi (2006:12) mengartikan nyadran sebagai tradisi mengunjungi makam leluhur yang diambil dari bahasa Sansekerta "sadra". Pada sebagian besar masyarakat Jawa, kata sadra kemudian dirubah dengan sadran atau nyadran yang memiliki arti ziarah kubur. Di dalam tradisi nyadran, masyarakat memanjatkan doa selamat dan selamatan (Istiqomah, 2013:44; Nurmalitasari, 2012). Nyadran merupakan ritual bersifat seremonial untuk membersihkan kubur atau makam leluhur. Tidak hanya itu, nyadran dalam pelaksanaannya selalu diiringi dengan selamatan (kenduri), membuat jajanan pasar khas nyadran, kue sesaji seperti apem, kolak, ketan, pasung, pisang raja, dan aneka makanan sebagai bentuk sesaji sebagai piranti doa.

Tradisi Nyadran awalnya sebuah bentuk upacara pemujaan roh $^{3}$ para leluhur yang dilakukan oleh penganut Hindu-Budha (Dhavamony, 1995:72). Nyadran lekat dengan ajaran animisdinamis masyarakat pada saat itu. Sejak Islam masuk ke Indonesia sekitar abad ke-13, khususnya Jawa, nyadran telah ditransformasikan dalam bentuk dan makna yang berbeda (Purwadi, 2009:2). Pemujaan kepada roh para leluhur dirubah menjadi wujud ritual yang menunjukkan tanda bakti seseorang kepada ahli kubur yang telah mendahuluinya (dalam Islam sering disebut tanda bakti kepada orang tua dikenal dengan birul walidain).

Suyitno (2001:107) menjelaskan bahwa nyadran sudah ada sejak zaman Kerajaan Majapahit ${ }^{4}$ sekitar tahun 1284 yang biasa disebut masyarakat Majapahit dengan nama craddha yang berarti keyakinan atau kepercayaan. Pelaksanaan craddha menggunakan puji-pujian dan sesaji sebagai perlengkapan ritualnya. Masyarakat pada saat itu percaya bahwa para leluhur yang

3 Pemujaan kepada roh leluhur dipercaya sebagai ritual yang memiliki peran penting dalam kehidupan penganutnya, karena ada kepercayaan bahwa roh-roh leluhur selalu mengawasi nasib mereka. Roh-roh leluhur diyakini mampu mendatangkan hadiah, memberi hukuman, rizki, menjaga kesejahteraan, member keselamatan. Para roh leluhur menurut tradisi Cina kuno menuntut pelayanan dan ketaatan para ahli waris.

4 Nyadran di Kerajaan Majapahit adalah ritual Ratu Tribuana Tungga Dewi, Raja Majapahit kala itu. Ratu Tribuana Tungga Dewi saat itu ingin berdoa kepada ibunya bernama Ratu Gayatri, dan roh nenek moyangnya yang diperabukan di candi Jobo. Ratu Tribuana menyiapkan sesaji yang ditujukan kepada para dewa berupa makanan, air suci, bungan setaman, kemenyan, dan dupa. Kebiasaan ini selanjutnya dilakukan oleh Prabu Hayam Wuruk, dengan melakukan ziarah ke kubur para leluhur. 
telah meninggal, dapat mempengaruhi kehidupan anak cucu atau keturunannya, mengganggu ataupun berhubungan dengan sanak keluarganya (Purwadi, 2006:109). Ritual Nyadran menjadi makin kuat setelah Walisongo melakukan dakwah Islam di pulau Jawa. Abad ke 15, Walisongo melakukan kompromi budaya dan menjadikan nyadran sebagai media dakwah Islam. Makna nyadran mengalami pergeseran dari sekedar pemujaan kepada roh leluhur menjadi ritual penghargaan kepada leluhur yang dianggap suci dan sakral. Nyadran dilaksanakan menjelang Ramadhan (Purwadi, 2009:5).

Nyadran biasanya dilaksanakan disekitar makam leluhur dengan berbagai variasi hidangan dan jajan pasar yang menghiasi hampir seluruh kawasan acara nyadran. Tradisi nyadran diikuti oleh semua warga masyarakat yang memiliki ahli kubur di suatu komunitas tertentu. Nyadran diikuti oleh semua jenis kelamin, semua umur, latar belakang sosial, pendidikan, status pekerjaan (Ghazalba, 1986:144). Semua warga akan menjadikan momen ini sebagai perwujudan eksistensi diri dengan alam semesta, wujud diri dengan lingkungan sosial, dan wujud diri dengan dimensi spiritual. Relasi yang dibangun dalam ritual nyadran adalah hubungan harmonis antara manusia dengan alam, lingkungan sosial, dan kekuatan ghaib. Otto dalam Koentjoroningrat (1980:65) menyebutkan bahwa semua sistem ritual Jawa yang dibingkai dalam ajaran agama tertentu selalu berpusat pada konsep ghaib yang dianggap memiliki kekuatan dahsyat (tremendum), kekuasaan (power), dan bersifat keramat (sacer) oleh manusia. Nyadran merupakan salah satu bentuk ritual yang bersifat keramat bagi masyarakat yang meyakininya.

\section{Konsep Nyadran Warga Kedungrejo Kemusu Kabupaten Boyolali Periode Orde Baru}

\section{Histografi Nyadran sebuah Peristiwa Sejarah}

Nyadran di Kemusu Kabupaten Boyolali seperti telah dijelaskan pada bagian awal tulisan, merupakan tradisi yang bersifat menyejarah, ditinjau dari proses pembentukannya. Nyadran di Kemusu, baru diselenggarakan pada era tahun 80-90an. Persistiwa sejarah ini lahir bertepatan dengan tekanan yang dialami warga Kemusu akibat program pembanngunan Waduk Kedung Ombo (WKO) pada zaman pemerintahan Orde Baru (Orba). Berbeda dengan pelaksanaan Nyadran di beberapa komunitas masyarakat Jawa. Pada sebagian besar masyarakat Jawa, tradisi ini diwariskan secara turun menurun, namun di Kedungrejo Kemusu Boyolali tradisi nyadran baru dilaksanakan pada masa pemerintahan era Suharto yaitu sejak dicanangka proyek pembangunan Waduk Kedung Ombo. Untuk memberikan gambaran histografi nyadran sebagai peristiwa sejarah, maka penulis mengawali tulisan ini dari kondisi masyarakat Kedungrejo Kemusu Boyolali era tahun 80-90an.

Kemusu Kabupaten Boyolali merupakan salah satu kawasan yang menjadi bagian integral dari proyek pembangunan WKO. Kemusu secara geografis merupakan daerah genangan dari WKO yang memiliki kualitas tanah relatif subur dibandingkan dengan Kabupaten Grobogan dan Sragen. ${ }^{5}$ Kemusu meliliki tiga belas desa, dan sembilan diantaranya terkena proyek genangan air

5 Kabupaten Sragen dan Purwodadi adalah kawasan yang juga menjadi bagian integral dari pembangunan proyek Waduk Kedung Ombo. Luas tanah yang harus dibebaskan pada pembangunan Waduk Kedung Ombo 6,125 Ha. Untuk wilayah Kabupaten Boyolali tanah yang harus dibebaskan di kecamatan Kemusu seluas 3.182 Ha yang 
Waduk Kedung Ombo (Dokumen Pemerintah Kabupaten Boyolali, 2011). Tahun 1981 proses pembangunan Waduk Kedung Ombo dimulai. ${ }^{6}$ Menurut Mahmudi (2015), hampir seluruh masyarakatnya menggantungkan diri pada potensi pertaniannya, namun sejak bergulirnya program pembangunan Waduk Kedung Ombo (mulai tahun 1985), menjadikan masyarakatnya hidup dalam kesulitan. ${ }^{7}$ Terjadi pemaksaan penandatanganan dan atau cap jempol dalam proses pembebasan lahan yang akan dijadikan WKO.

Penggenangan paksa menyebabkan warga yang tidak sempat bermigrasi atau direlokasi harus meninggalkan rumah dan lahan pertanian mereka. Warga bahkan tidak sempat membawa barang berharga yang mereka miliki seperti ternak, maupun perabot rumah tangga. Genangan air telah menenggelamkan sejumlah Desa di Kelurahan Wonoharjo seperti Dukuh Kedung Uter, Kedung Lele, Jetis dan Ceremai. Akhirnya penduduk beramai-ramai pindah mencari tempat yang lebih tinggi. Permasalahan muncul ketika warga masih bertahan di sekitar lokasi waduk pada elevasi 95 meter. Warga mulai kekurangan air bersih, ketersediaan sumber pangan menipis, akses ke luar desa sulit, warga mulai hidup dalam gambaran bencana kelapar. Pada April 1989, warga hidup dalam kelaparan, karena tidak ada lagi sumber pasokan pangan (Mahmudi, 2015). Warga semakin kebingungan dan beberapa dari mereka tidak mampu bertahan hidup akibat kelaparan. Muncul sosok Romo Mangunwijoyo (dikenal dengan mbah Mangun) yang merasa iba dengan nasib warga Kemusu. Bersama dengan komunitasnya mbah mangun datang ke Kemusu, mengajak seluruh warga untuk memanjatkan doa dan mohon pengampunan atas segala kesalahan yang telah dilakukan (Harian Kompas, 6 Maret 1989). Sebagai ungkapan rasa syukur, maka warga menggelar doa bersama yang kala itu didampingi oleh Hammam Ja'far. ${ }^{8}$ Melalui

meliputi sepuluh desa, diantaranya Wonoharjo, Lemahireng, Watugede, Nglanji, Genengsari, Kemusu, Ngrakum, Sarimulyo, Bawu, dan Klewor. Kabupaten Sragen adalah kecamatan Miri dan Sumber Lawang desa yang tergenang antara lain Lorog, Gilirejo, Soka, Boyolayar, dan Ngargomulyo, sedangkan Grobogan dengan wilayah genangan pada garis ketinggian air 92,5 meter yang menyangkut kawasan 22 desa (Karmono, 2005; Hatta, 2002:43; Stanley, 1994:12; Dokumen of The World Bank LN.2543-IND, 1985).

6 Proyek dimulai dengan pembuatan jalan masuk ke lokasi bendungan dari Monggot ke Kedung Ombo, kemudian kantor lapangan untuk investigasi dan pelaksanaan, gedung laboratorium untuk penyimpanan sampel geologi dan bengkel lapangan, perumahan karyawan, jalan penghubung untuk sarana angkutan material dari Juwangi ke Kedung Ombo. Pembangunan sarana penunjang ini hingga tahun 1985.

7 Menteri Dalam Negeri pada saat itu Soepardjo Rustam dalam rapat kerja anggota Komisi II DPR RI tanggal 25 November menyebutkan bahwa besarnya uang ganti rugi bagi pembebasan tanah yang terkena proyek pembangunan waduk sebesar Rp3.000,- per meter persegi. Namun akhirnya mengenai besarnya uang ganti rugi tanah ini, pemerintah hanya mengacu pada SK Gubernur Kepala Daerah Tingkat I Jawa Tengah tertanggal 2 Mei 1985 No. 593/135/1987 yang menetapkan besarnya uang ganti rugi tanah sebesar Rp.700,- per meter persegi (suara merdeka, 25 Maret 1989 dalam Tuminah, http://merahputihku-tuminah.blogspot.com/2012/08/ perlawanan-rakyat-dalam-kasus.html; Waduk Kedung Ombo (Bendungan Raksasa di 3 Kabupaten); https:// ekosospol.wordpress.com/2011/08/06/tragedy-waduk-kedung-ombo-sejarah-teror-yang-di-sponsori-negara/, diakses 15 April 2015).

8 Hammam Ja'far adalah pengasuh pondok pesantren Pabelan Magelang yang sangat intensif mendampingi warga masyarakat bertahan di lokasi, dan membangun sekolah darurat untuk sekitar 3500 anak-anak, serta membangun sarana seperti rakit untuk transportasi warga yang sebagian desanya sudah menjadi danau. Warga yang bertahan juga mengalami teror, intimidasi dan kekerasan fisik akibat perlawanan mereka terhadap proyek tersebut. Pemerintah memaksa warga pindah dengan tetap mengairi lokasi tersebut, akibatnya warga yang bertahan kemudian terpaksa tinggal di tengah-tengah genangan air. Ustaz Ja'far membantu warga berjuang menuntut haknya atas ganti rugi tanah yang layak. 
Mangkunegaran Solo, warga mulai melaksanakan ritual "sadra" yaitu ritual membersihkan hati (Rohman, 2010).

\section{Pelaksanaan Nyadran di Kedungrejo Kemusu Boyolali}

Ritual sadra awalnya adalah ritual yang dipergunakan untuk memersihkan hati dari semua bentuk kesalahan, dan kehilafan. Kondisi penuh tekanan, kesengsaraan, dan kemarahan warga pada saat itulah menjadikan warga Kemusu, mengalami transformasi nilai personal dan sosial. Kondisi penuh tekanan ini justru menjadi momen bersejarah lahirnya Nyadran di Kemusu Kabupaten Boyolali. Nyadran awalnya hanya sebatas upaya ungkapan rasa syukur atas pertolongan Tuhan (Allah), yang telah melepaskan warga dari belenggu bencana kelaparan, keterpurukan, dan ketidak berdayaan. Nyadran berubah menjadi tradisi yang sangat diagungkan dan bersifat sakral. Nyadran tidak hanya sebatas ritual keagamaan turun menurun, tapi lebih dari itu, menurut proses pembentukannya menjadi peristiwa bersejarah (momen historis) bagi masyarakat Kemusu. Bayan Yanto menyebutkan bahwa telah terjadi momen sejarah yang tidak dapat dilupakan dari pelaksanaan nyadran di wilayah Kemusu.

Awalnya nyadran adalah sebuah bentuk rasa syukur. Masyarakat menganggap bahwa nyadran di Kemusu adalah cikal bakal momen sejarah nyadran di kabupaten Boyolali. Menurut warga nyadran adalah sadra yang berarti bentuk ungkapan rasa syukur kepada Allah karena telah terhindar dari bencana kelaparan, dan sebagai cikal bakal kebangkitan tatanan sosial masyarakat Kemusu. Lebih lanjut dijelaskan bahwa sadra dilakukan sebagai bentuk permohonan keselamatan kepada Tuhan atas bencana yang menimpa wilayah Kemusu. Sadranan yang dilakukan awalnya memang berkaitan dengan persoalan perlindungan dari Tuhan. Selain sebagai upaya memohon perlindungan, sadranan menjadi sarana ritual penghormatan kepada leluhur.

Sadranan yang dilakukan di desa Kedungrejo Kemusu Boyolali secara historis baru dilakukan pasca peresmian penggenangan Waduk Kedung Ombo. Pada saat warga kedungrejo mengalami bencana kelaparan, dan krisis air bersih, warga masyarakat menjadi sangat menderita dan merasa prihatin. Dijelaskan oleh mbah Jamal bahwa warga Kedungrejo merupakan wilayah yang memiliki dampak paling besar dari pembangunan Waduk Kedung Ombo. Melalui Mangkunegaran Solo dan Hammam Ja'far, maka warga masyarakat diajak untuk melakukan doa bersama, bertujuan sebagai bentuk permohonan dan perlindungan dari Tuhan. Bertepatan dengan bulan Sya’ban masyarakat Kedungrejo menyelenggarakan doa dan selamatan untuk kehidupan mereka. Ritual sadranan awalnya dilakukan di depan pintu akses menuju Kedung Ombo, tempt di mana warga masyarakat melakukan aktivitas mincing. Dipilihnya tempat ini menurut mbah Jamal, lebih dikarenakan agar masyarakat dapat mengenang peristiwa penggenangan Waduk Kedung Ombo yang saat itu telah menenggelamkan rumah-rumah, sawah, dan seluruh harta benda warga. Ada upaya refleksi sekaligus peringatan, agar kehidupan yang akan datang jauh lebih baik dan terhindar dari malapetaka, kesengsaraan, dan kesulitan seperti awal proyek pembangunan Waduk Kedung Ombo.

Ritual sadranan awalnya hanya diikuti oleh warga asli dari dua desa yaitu Kedungrejo dan Kedungmulyo Kemusu Boyolali. Dua desa ini merupakan pintu masuk Kedung Ombo 
dari wilayah Selatan, dan memiliki akses lebih mudah dibandingkan desa lainnya. Berdasarkan kesepakatan masyarakat Kedungrejo dan Kedungmulyo kegiatan sadranan dipusatkan di Kedungrejo, dipimpin juru kunci Kedung Ombo. Pelaksanaan sadranan pada saat itu memiliki banyak perlengkapan yaitu gunungan tumpeng, bubur tujuh warna, jajan pasar, apem, ketan, pisang raja, ingkung, tombak dan keris Mangkunegaran Solo (sekarang disebut Kasultanan Surakarta), serta kembang setaman, perlengkapan lainnya adalah tasbih, dan tikar mendhong. Yang paling unik, saat ritual sadranan dimulai juru kunci melaksanakan "padusan" dengan busana putih dan membawa tombak serta keris Mangkunegaran Solo, para laki-laki duduk melingkar disekitar perlengkapan sadranan, para perempuan berdiri mengelilingi suami masing-masing, dengan memanggul tenong di kepalanya. Tenong tersebut berisi beras dan hasil bumi lainnya seperti ketela pohon, buah-buahan, padi, dan hasil ternak milik masing-masing keluarga.

Sadranan dilanjutkan dengan ritual doa dan selamatan. Saat ritual doa dilakukan oleh juru kunci, para laki-laki membaca bacaan tasbih, takbir, dan tahmid. Para istri berada dibelakang suaminya menurunkan tenong dan menyusun beberapa barang bawaan yang merupakan hasil bumi di atas tikar mendhong, selanjutnya dikumpulkan dan diikat dengan mori dan dibawa menuju ke dalam lingkaran yang dibentuk para laki-laki dan mendekati jurukunci. Setelah doa bersama diselesaikan, juru kunci menuju tempat gaman atau senjata diletakkan (biasanya gaman diletakkan disamping gunungan tumpeng, dan dipusat sajian makanan yaitu: apem, ketan, pisang raja, ingkung, jajan pasar, dan bubur tujuh warna, dengan cara berjalan seperti abdi dalem keraton.

Proses sadranan dilanjutkan doa selamatan. Doa selamatan terdiri dari limo perkoro (lima perkara). Perkara pertama, adalah doa yang ditujukkan kepada Allah swt; perkara kedua, doa yang ditujukan kepada Rasulullah saw; perkara ketiga, doa yang ditujukan kepada penjaga gaman; perkara keempat, doa yang ditunjukkan kepada penjaga Kedung Ombo; dan perkara kelima, adalah doa yang ditujukan kepada seluruh keluarga dan ahli kubur yang telah mendahului. Sadranan diakhiri dengan mengitari Waduk Kedung Ombo menggunakan gethek berisi hasil bumi yang dibungkus tikar mendhong, gunungan tumpeng, dan jajan pasar yang dibawa oleh juru kunci Kedung Ombo. Juru kunci membawa kembali perlengkapan ritual menuju ke tempat semula. Di tempat ritual, beberapa perempuan menerima kembali perlengkapan yang telah di bawa oleh juru kunci. Setelah semua perlengkapan diturunkan, maka melalui juru kunci melakukan ritual makan bersama sebagai akhir dari ritual sadranan.

Kebiasaan yang telah menjadi kebudayaan dan dimiliki oleh komunitas tertentu, selain dikarenakan proses adaptasi dengan kondisi alam, interaksi antar penduduk, juga mengakibatkan terjadinya percampuran budaya. Tradisi sadranan atau nyadran mengalami perubahan tata cara dalam pelaksanaan yang sangat bervariasi dan interaktif. Interaksi ini akan menimbulkan difusi maupun akulturasi kebudayaan yang akan menimbulkan perubahan perilaku para keluarga di Kemusu. Awalnya keluarga Tualah (sesepuh) yang melaksanakan sadranan, namun pada saat ini keluarga muda pun ikut terlibat dalam ritual. Keikutsertaan keluarga muda dalam pelaksanaan sadranan di Kedungrejo Kemusu Boyolali merupakan salah satu implikasi sosiologis dalam 
tinjauan filsafat serajarah pragmatis. Ritual sadranan yang dilakukan oleh masyarakat Kedungrejo Kemusu Boyolali, dari tahun 80-90an masih merupakan ritual yang memiliki nilai sakralitas tinggi. Ini dibuktikan dari perlengkapan hingga proses pelaksanaan sadranan yang memang terkesan sangat hidmat dan sakral. Tidak ada canda tawa, semua ritual berisi bacaan doa.

\section{Transformasi nilai dari Momen Sejarah Nyadran di Kedungrejo Kemusu}

Tahun 80-90an, nyadran hanya sebatas peristiwa sejarah akibat kondisi masyarakat Kemusu yang sedang dilanda bencana kelaparan panjang dari pembangunan proyek Waduk Kedung Ombo (WKO) masa pemerintahan Orde Baru (Orba). Telah terjadi transformasi nilai pada ritual Nyadran di Kemusu kabupaten Boyolali. Nilai sakralitas nyadran sebagai ungkapan rasa syukur terbebas dari bencana kelaparan dan tekanan pemerintah akibat proyek WKO, telah berubah menjadi nilai tradisi lintas budaya dan agama. Awal tahun 95-an, tradisi sadranan oleh masyarakat Kemusu lebih dikenal dengan nyadran. Ritual nyadran yang dilakukan pun sudah tidak sama seperti zaman Orde Baru. Ritual yang dilakukan cenderung lebih mengedepankan aspek sosial, rasa persaudaraan, dan kebersamaan dalam bingkai lintas budaya (Riyadi, 2015:5). Nyadran di Kemusu tidak lagi dipimpin oleh juru kunci Kedung Ombo, melainkan modin atau ustaz. Jenis makanan lebih bervariasi sesuai dengan kemampuan masyarakatnya. Proses pelaksanaan nyadran dilaksanakan oleh semua masyarakat dari berbagai latar belakang budaya, profesi, maupun lintas agama. Nyadran di Kedungrejo memiliki pergeseran makna dari sebuah ritual keagamaan yang sakral menjadi ritual yang mengarah pada bentuk wisata rohani. Hidangan yang dibawa masyarakat sangat variatif. Tradisi nyadran di Kedungrejo yang awalnya hanya diikuti oleh dua desa yaitu Kedungrejo dan Kedungmulyo, kini telah diikuti oleh semua warga baik dari dalam kecamatan Kemusu maupun luar Kemusu seperti wilayah Andong, Klego, Gemolong dan wilayah lain di sekitar Kecamatan Kemusu.

\section{E. Analisis}

Nyadran atau sadranan yang dilakukan di desa Kedungrejo telah membawa perubahan yang signifikan pada kehidupan masyarakat di sekitar WKO. Sadranan yang awalnya hanya sebatas upaya permohonan keselamatan dan terhindar dari bala telah berubah menjadi tradisi tahunan yang telah berhasil mengakomodasikan kepentingan agama, budaya, dan ras yang berbeda. Nyadran di Kedungrejo Kemusu Boyolali apabila ditinjau dari filsafat sejarah pragmatis, merupakan sebuah ritual yang memang dilakukan masyarakat karena alasan-alasan praktis atau kegunaan dalam mempelaari masa lalu. Melalui kajian filsafat sejarah pragmatis, hal yang ingin diperoleh adalah mempelajari nilai-nilai (value) yang terkandung dalam peristiwa sejarah yang dapat dijadikan inspirasi, motivasi, asas, ataupun pedoman hidup yang memberikan landasan moral (Abdullah, Taufiq, dan Suryomiharjo, 1985:13).

Berdasarkan pada kemunculan tradisi sadranan pada tahun 80-90an, menunjukkan bahwa sebenarnya sadranan adalah ritual yang dilakukan dalam rangka mendapatkan keselamatan dan terhindar dari bala, yaitu kelaparan dan kekurangan air bersih pada saat proyek genangan Waduk Kedung Ombo. Masyarakat Kedungrejo mengalami masa paceklik karena sudah tidak 
ada lagi bahan makanan yang tersedia, sumber daya alam sudah tidak mencukupi, air bersih tidak tersedia, sementara rumah-rumah dan harta benda mereka tenggelam. Datangnya bantuan dari Mangkunegaran Solo, dan peran serta Mbah Mangun dan Hammam Ja'far, menjadikan masyarakat Kedungrejo kembali memiliki semangat hidup, motivasi dan inspirasi baru. Nilai moral yang dapat diambil dari pelaksanaan nyadran tetrdiri dari dua hal, pertama nilai moral secara vertikal dan nilai moral bersifat horizontal (Hadi dan Muryati, 2013:111).

Nilai moral secara vertikal berarti bahwa menjelaskan relasi yang harus dibina secara spiritual, atas relasi harmonis antara manusia dengan sang pencipta. Nilai moral secara horizontal menjelaskan relasi positif yang harus dibina antara manusia dengan manusia, manusia dengan hewan, dan lingkungan alam (Ranjabar, 2006:19). Menjalin relasi harmonis dengan pencipta (Allah swt) dapat dilakukan bentuk ritual ibadah. Nyadaran bagi warga Kedungrejo dalam hal ini memiliki nilai moral sebagai wujud ungkapan rasa syukur, permohonan agar terhindar dari bencana, dan wujud penghambaan. Dalam konsep ini, maka dapat dipandang bahwa nyadran merupakan sebuah asas kehidupan dihadirkan dalam diri individu dan kelompok. Relasi kedua tradisi nyadran adalah relasi horizontal antara manusia dengan manusia. Ritual nyadran di Kedungrejo dilaksanakan untuk menunjukkan hubungan yang harmonis antara individu dengan leluhurnya atau nenek moyangnya. Nyadran adalah bentuk penghormatan, penghargaan, dan wujud kebaktian (birul walidain) kepada para leluhur dan menajatkan doa selamat (Nurmalitasari, 2012). Makna filosofis dari hubungan ini menunjukkan bahwa seorang anak atau ahli kubur, diharapkan dalam kehidupannya selalu menunjukkan rasa hormat dan berbakti kepada para ahli kuburnya yang ditunjukkan dengan cara selalu mendoakan dengan hati yang tulus dan ikhlas. Makna lain dari hubungan kemanusiaan menunjukkan bahwa manusia meskipun sudah tidak lagi memiliki ikatan secara jasmaniah, mereka masih memiliki ikatan secara spiritual.

Hubungan manusia dengan hewan dan lingkungan alam yang dapat diambil dari tradisi nyadran Kedungrejo bahwa manusia dalam kehidupan sehari-harinya harus senantiasa menjadi pengelola yang bertanggung jawab, artinya dapat memperlakukan hewan dan lingkungan alam secara seimbang, tidak melakukan perusakan, sehingga menghindarkan diri dari bencana. Bagi sebagian besar masyarakat Kedungrejo Kemusu memandang bahwa bencana paceklik dan kelaparan yang melanda mereka pada tahun 80-90an adalah salah satu bentuk ketidakmampuan manusia mengelola alam dan sumber daya secara bertanggung jawab. Ini terbukti setelah genangan air dioperasikan di lembah Kedung Ombo, semua sawah, harta benda dan sumber bahan makanan hilang, dan mereka tidak memiliki sumber makanan baru. Menurut penulis, tradisi nyadran di Kedung Ombo mencerminkan bentuk kesadaran baru dari kelompok masyarakat untuk lebih mencintai alam dan lingkungan sekitar, menjaga lingkungan, dan melakukan pengelolaan secara tepat.

Nyadran di Kedungrejo Kemusu dalam pelaksanaannya memiliki perlengkapan yang sangat beragam dan bersifat sakral. Perlengkapan yang harus ada pada saat itu adalah gunungan tumpeng, bubur tujuh warna, jajan pasar, apem, ketan, pisang raja, ingkung, tombak dan 
keris Mangkunegaran Solo, serta kembang setaman, perlengkapan lainnya adalah tasbih dan tikar mendhong. Gunungan tumbeng berisi nasi putih dan kuning yang dibentuk kerucut di atasnya diberi hiasan cabai merah dan terasi memiliki makna filosofis bahwa manusia dalam kehidupannya. Nasi kuning-putih dimaknai agar segala hajat dikabulkan oleh Allah swt karena didasarkan pada niat ikhlas dan hati yang bersih. Cabai dan trasi menggambarkan bahwa dalam kehidupan, manusia selalu ditunjukkan jalan yang benar, dihindarkan dari segala mara bahaya, dan memiliki kemanfaatan bagi sesama. Tumpeng membawa semangat atau motivasi untuk bekerja lebih giat, semangat bahwa apa yang dilakukan oleh warga selalu mendatangkan riski melimpah, semakin menumpuk, dan tidak akan pernah habis.

Bubur tujuh warna melambangkan bahwa harapan dan cita-cita. Warna merupakan simbol kehidupan yang akan manusiayang memiliki berbagai makna. Merah melambangkan keberanian. Putih bermakna kesucian. Hitam artinya kecerdasan. Kuning merupakan simbol kekuatan. Biru berarti kesetiaan. Merah muda menandakan cinta kasih dan ungu sebagai lambang ketenangan. Warna-warna tersebut merupakan gambaran dalam kehidupan seseorang yang akan menghadapi banyak pilihan dan rintangan yang harus dilaluinya. Bubur tujuh warna yang disusun dari warna gelap ke warna terang menggambarkan masalah yang dihadapai mulai dari yang berat sampai yang ringan, dengan tujuh buah pintu. Harapannya seberat apa pun pasti akan ada jalan keluarnya (mendapatkan pitulungan dari Tuhan Yang Maha Esa).

Kembang setaman terdiri dari air, bunga kenanga, bunga mawar, bunga kantil, daun beringin, andong, puring, tunas pohon pisang raja kecil, mayang, dan daun jambe. Makna dari kembang setaman dalam ritual kehidupan yang berkesinambungan, sebagai simbol penyiram penghuni Kedung Ombo agar tenteram, dan simbol menyambung kehidupan yang memiliki hajat. Jajan pasar jajan pasar adalah simbol keindahan dan keramainan. Maksud penggunaan jajan pasar adalah sebuah harapan indah, dan agar kehidupan selalu diramaikan dengan orang-orang seperti di pasar. Jajan pasar terdiri dari bermacam-macam makanan ringan yang biasa tersedia di pasar (Ni'mah, Sulistyorini, dan Kamal, tt:5). Tenong adalah wadah terbuat dari anyaman bambu, berbentuk kotak-kotak yang secara filosofis memiliki arti bahwa satu silaturrahmi dan kerukunan, menjalin kekompakan dalam masyarakat.

Gaman atau pusaka adalah alat untuk membela diri dari serangan musuh, dan binatang atau untuk membunuh musuh. Namun kemudian fungsi dari senjata tajam seperti keris pusaka atau tombak pusaka itu berubah. Gaman menimbulkan rasa keberanian yang luar biasa kepada pemilik atau pembawanya. ${ }^{9}$ Hubungan keris dengan sarungnya secara khusus oleh masyarakat Jawa diartikan secara filosofi sebagai hubungan akrab, menyatu untuk mencapai keharmonisan hidup di dunia. Maka lahirlah filosofi "manunggaling kawula - Gusti", bersatunya abdi dengan rajanya, bersatunya insan kamil dengan Penciptanya, bersatunya rakyat dengan pemimpinnya,

9 Orang menyebut itu sebagai piyandel, penambah kepercayaan diri, bahkan keris pusaka atau tombak pusaka yang diberikan oleh Sang Raja terhadap bangsawan Karaton itu mengandung kepercayaan Sang Raja terhadap bangsawan unggulan itu. Namun manakala kepercayaan sang raja itu dirusak oleh perilaku buruk sang adipati yang diberi keris tersebut, maka keris pusaka pemberian itu akan ditarik/diminta kembali oleh sang raja (Permadi, 2005, "Makna Tombak dan Keris bagi Masyarakat Jawa" dalam http://indokerisgallery.blogspot.com/2013/01/maknakeris-menurut-budaya-jawa.html, diakses 20 Mei 2015). 
sehingga kehidupan selalu aman damai, tentram, bahagia, sehat sejahtera.

Sajian makanan yang ada pada tradisi nyadran, menurut keyakinan masyarakat Jawa seperti kue apem, ketan, pasung, dan pisang raja memiliki makna filosofis. Apem berasal dari kata bahasa Arab afwan artinya permintaan maaf. Ketan berasal dari kata bahasa Arab yakni khathaan yang artinya menghindari perbuatan yang tidak terpuji, kata kolak berasal dari kata bahas Arab qola artinya mengucapkan dan pasung yang berbentuk tumpeng kecil memiliki makna filosofis memohon keselamatan kepada Tuhan. Budaya masyarakat yang sudah melekat erat menjadikan masyarakat Jawa sangat menjunjung tinggi nilai-nilai luhur dari kebudayaan itu (Handayani, 1995:7).

\section{F. Implikasi Psiko-sosio-religius Nyadran di Kedungrejo Kemusu Boyolali}

Ritual nyadran atau sadranan dalam tradisi masyarakat Jawa Muslim memiliki implikasi spiritual yang begitu luar biasa. Awalnya tradisi nyadaran hanya sebatas ritual kirim doa, mohon pertolongan dari Allah swt, atas bencana kelaparan dan kekuarangan air bersih akibat genangan Waduk Kedung Ombo, berubah menjadi sebuah tradisi tahunan yang ditujukan sebagai ungkapan rasa syukur atas rizki yang diberikan Tuhan. Nyadran juga menjadi media dalam mengakomodasi kepentingan ritual lintas agama. Nyadran pada saat ini tidak hanya menjadi milik umat Muslim, melainkan milik seluruh manusia yang mempercayainya.

Nyadran di Kedungrejo, tidak hanya menjadi milik warga Kedungrejo, melainkan menjadi milik seluruh warga di sekitar Kedung Ombo bagian Selatan seperti Andong, Klego, Gemolong, Simo, dan beberapa wilayah Selatan Kedung Ombo. Nyadran yang awalnya merupakan tradisi bersifat sakral, saat ini telah mengalami pergeseran menjadi seremonial yang dapat menjadi potensi wisata. Pada saat ini realitas nyadran di beberapa wilayah tidak lagi menggunakan peralatan sesaji, makanan tertentu, bahkan cara-cara tertentu. Pelaksanaan nyadran menjadi bersifat umum, yang dilakukan dengan membawa makanan beranekak ragam, yang tujuannya sebagai bentuk sedekah atau amal jariah yang nantinya akan dimakan secara bersama atau saling bertukar makanan antara satu orang dengan orang lain. Pergeseran bentuk dan cara pelaksanaan nyadran menunjukkan salah satu bentuk perkembangan budaya yang sangat dinamis, dan pada suatu saat pasti bentuk dan cara nyadran juga akan selalu berubah sesuai dengan situasi, kondisi, kebutuhan dan tingkat perkembangan masyarakatnya.

Untuk bisa menemukan implikasi psiko sosio religious, maka penulis akan mengawali dari adanya hubungan dialektika antara budaya dan doktrinasi agama tertentu, yang selanjutnya membentuk identitas baru dalam relasi sosial masyarakat. Dialektika tersebut hadir dari atribut sosial-kultural dalam konteks waktu, situasi, dan kondisi tertentu (Jamil, 2012:3). Nyadran dengan kemeriahannya pada saat ini telah memunculkan pemahaman yang beragam. Nyadran merupakan suatu bentuk reorientasi dan reinterpretasi budaya. Hasanah (2013) menjelaskan bahwa tradisi pada msyarakat tertentu memberikan orientasi makna yang berbeda. Nyadran tidak hanya murni sebagai bentuk ritus keagamaan, melainkan ritus sosial dan ritus kejiwaan. Dalam pengertian keagamaan tentu menjelaskan hubungan antara manusia dengan penciptanya. 
Implikasi filosofis yang hadir dalam sebuah ritual ini tidak hanya dalam perspektif religius sebagai wujud ungkapan doa dan pertolongan, melainkan memiliki perkembangan makna baik secara psikologis maupun sosiologis (Hasanah, 2013:3). Implikasi religius dari tradisi nyadran, menyangkut persoalan internalisasi nilai-nilai ajaran agama dalam kehidupan. Nyadran mengandung nilai penghambaan, kedermawanan, keshalehan. Aspek nilai inilah yang akan dimanfaatkan oleh manusia dalam mengemban tugas kemanusiaannya yaitu sebagai Abdullah dan khalifah di muka bumi. Sebagai hamba Allah yang senantiasa meningkatkan keimanan dan ketakwaan melalui penghambaan. Manusia sebagai khalifah melalui tradisi nyadran dapat menghadirkan nilai-nilai kepemimpinan, pengelolaan, pengolahan lingkungan sosial secara bertanggung Jawab.

Implikasi psikologis dari ritual nyadran pada saat ini, tidak hanya sebatas pada bentuk penghambaan personal, melainkan mengalah pada pembentukan dinamika psikologis yang lebih komplek. Dinamika psikologis ini diwujudkan dalam bentuk keakraban, kedekatan, respon emosional positif, rasa saling mengasihi, berbagi. Dinamika psikologis nyadran adalah perubahan sikap dan perilaku positif, bersifat integral-komprehensif. Artinya, nyadran membentuk seseorang memiliki kedewasaan dan kematangan dalam bersikap, memandang agamanya secara universal, dan mengembangkan sikap toleran. Nyadran melahirkan sikap dan perilaku motivasional dan inspiratif. Motivasi untuk hidup dalam kedamaian, ketentraman, keunggulan, dan kesejahteraan. Selalu bersemangat dan memiliki inspirasi dalam menjunjung tinggi nilai-nilai tradisi nyadran.

Watak dan perilaku yang baik tentu akan mengarahkan diri seseorang tetapi juga sebagai proses sosial. Proses sosial ini merupakan implikasi sosiologis atas tradisi dan ritual yang dilakukan. Nyadran pada setiap pelaksanaannya selalu menampilkan hubungan harmonis dari rekasi dengan komunitas lain. Hal ini dikarenakan, nyadran tidak lagi menjadi milik komunitas tertentu, namun sekarang menjadi milik banyak komunitas, tentu realitas ini membawa dampak proses interaksi ${ }^{10}$ yang berbeda (Ahmadi, 1989:70). Implikasi sosiologis dari ritual nyadran adalah bentuk hubungan yang harmonis antara ahli waris dengan nenek moyangnya yang dibingkai dalam konsep birul wa lidain. Nyadran juga menjadi salah satu bentuk perekat sosial, sarana membangun jati diri bangsa dan nasionalisme. Nyadran dalam prosesinya, terdiri dari banyak orang dengan latar belakang berbeda, dan berkumpul dan duduk bersama tanpa ada sekat-sekat dalam kelas sosial dan status sosial, tanpa ada perbedaan agama dan keyakinan, golongan ataupun partai.

Nyadran bagi masyarakat Kedungrejo, tidak lagi hanya dihadiri oleh kaum tua, melainkan keikutsertaan keluarga muda dalam pelaksanaan nyadran. Nyadran bagi komunitas masyarakat urban secara sosiologis juga membawa makna tersendiri, pelaksnaan nyadran sering dianggap

10 Ada empat reaksi tindakan (a) integrative-ekspresif bersifat positif dan menyatakan dorongan kejiwaan termasuk perbuatan tolong menolong, member pujian, rasa setia kawan, seperti memberi sugesti, pendapat, dan penjelasan, (c) tindakan pengajuan pernyataan berupapermintaan orientasi, dan pendapat, (d) tindakan integrativeekspresif bersifat negative dan menyatakan dorongan kejiwaan menghindar, ketegangan, melawan, pertentangan dan penngunduran diri (Faizah, dkk., 2001:136) 
sebagai ritual yang justru lebih penting dari perayaan hari raya Idul fitri. Masyarakat yang tinggal di kota rela pulang "mudik" mengambil cuti atau libur kerja untuk menghadiri nyadran di Kedungrejo. Suasana bulan Sya'ban menjadi lebih ramai dibandingkan dengan bulan Syawal (menjelma menjadi refleksi wisata rohani). Masyarakat yang disibukkan dengan aktivitas kerja yang banyak menyedot tenaga, pikiran dan waktu sehingga mengabaikan religiusitas. Melalui nyadran, seakan tersentak kesadaran hati nuraninya untuk kembali bersentuhan dan bercengkrama dengan nilai-nilai agama. Implikasi sosiologis lain dari nyadran di Kedungrejo Kemusu dijadikan sebagai salah satu sarana pariwisata budaya, yang menghadirkan berbagai macam pertunjukkan perahu layar, festival layang-layang, bahkan aneka perlombaan.

\section{G. Simpulan}

Kajian filsafat sejarah pragmatis ingin memperoleh dan mempelajari nilai-nilai (value) yang terkandung dalam peristiwa sejarah yang dapat dijadikan inspirasi, motivasi, asas, ataupun pedoman hidup yang memberikan landasan moral.

Berdasarkan pada proses kemunculan tradisi sadranan pada tahun 80-90an, menunjukkan bahwa sebenarnya sadranan adalah ritual yang dilakukan dalam rangka mendapatkan keselamatan dan terhindar dari bala, yaitu bencana kelaparan dan kekurangan air bersih pada saat pembangunan proyek genangan Waduk Kedung Ombo pada masa pemerintahan Orde Baru. Momen sejarah inilah menjadi cikal bakal Nyadran di wilayah Kedungrejo Kemusu. Nilai moral yang dapat diambil dari pelaksanaan nyadran tetrdiri dari dua hal, pertama nilai moral secara vertikal dan nilai moral bersifat horizontal. Nyadran secara vertikal adalah bentuk penghambaan dan ungapan syukur kepada Allah swt. Nyadran secara horizontal adalah bentuk penghormatan, penghargaan, dan wujud kebaktian (birul walidain) kepada para leluhur dan menajatkan doa selamat. Makna filosofis dari hubungan vertikal menunjukkan pola perbadatan dan penghambaan, sedangkan secara horizontal menunjukkan rasa hormat dan berbakti nenek moyang, menjadi pengelola alam, dan lingkungan yang bertanggungjawab.

Menurut penulis, nyadran di Kedung Ombo mencerminkan bentuk transformasi nilai ajaran agama dalam bentuk kesadaran baru dari kelompok masyarakat untuk lebih mensyukuri karunia Tuhan, mencintai alam dan lingkungan sekitar, menjaga lingkungan, dan melakukan pengelolaan secara tepat. Nyadran di Kedungrejo Kemusu dalam pelaksanaannya memiliki perlengkapan beragam dan bersifat sakral. Perlengkapan yang harus ada adalah gunungan tumpeng, bubur tujuh warna, jajan pasar, apem, ketan, pisang raja, ingkung, tombak dan keris Mangkunegaran Solo, serta kembang setaman, perlengkapan lainnya adalah tasbih dan tikar mendhong.

Gunungan tumpeng memiliki makna filosofis bahwa manusia dalam kehidupannya selalu berhubungan dengan Allah. Nasi kuning-putih dimaknai agar segala hajat dikabulkan oleh Allah swt karena didasarkan pada niat ikhlas dan hati yang bersih. Tumpeng membawa semangat atau motivasi untuk bekerja lebih giat, semangat bahwa apa yang dilakukan oleh warga selalu mendatangkan riski melimpah, semakin menumpuk, dan tidak akan pernah habis. 
Bubur tujuh merupakan simbol kehidupan yang akan manusia yang memiliki berbagai makna. Kembang setaman dalam ritual berarti kehidupan yang berkesinambungan, Jajan pasar jajan pasar adalah simbol keindahan dan keramainan. Tenong secara filosofis memiliki arti bahwa satu silaturrahmi dan kerukunan, menjalin kekompakan dalam masyarakat. Gaman menimbulkan rasa keberanian yang luar biasa kepada pemilik atau pembawanya. Hubungan keris dengan sarungnya secara khusus oleh masyarakat Jawa diartikan secara filosofi sebagai hubungan akrab, menyatu untuk mencapai keharmonisan hidup di dunia, lahirlah filosofi "Manunggaling kawula - Gusti. Makna filosofis apem artinya permintaan maaf. Ketan berasal artinya menghindari perbuatan yang tidak terpuji, kata kolak artinya mengucapkan, dan pasung memiliki makna filosofis memohon keselamatan kepada Tuhan. Momen historis proses pembentukan nyadran di wilayah Kedungrejo Kemusu menjadi cikal bakal pelaksanaan nyadran pada era masa kini dan mendatang. Periode zaman Orde Baru menjadi penanda babak baru nyadran sebagai ritual sekaligus tradisi yang disakralkan di seluruh wilayah Kabupaten Boyolali. Meskipun formulasi pelaksanaan nyadran pada tahap awal pembentukannya dan kondisi saat ini jauh sangat berbeda, dan terkesan lebih inovatif dan kreatif.

Nyadran bagi warga Kedung Ombo memiliki implikasi psikologis berupa respon emosional positif dalam bentuk penerimaan, kesadaran, dan semangat bertahan hidup menghadapi bencana kelaparan; c) Implikasi sosiologis tradisi nyadran memunculkan rasa solidaritas sosial sebagai wujud penghormatan kepada para leluhur; d) implikasi religius merupakan ungkapan rasa syukur atas karunia Tuhan. Implikasi religius nyadran, menyangkut persoalan internalisasi nilainilai ajaran agama dalam kehidupan. Nyadran mengandung nilai penghambaan, kedermawanan, keshalehan. Aspek nilai inilah yang akan dimanfaatkan oleh manusia dalam mengemban tugas kemanusiaannya yaitu sebagai Abdullah dan khalifah di muka bumi. Implikasi psikologis dari ritual nyadran pada saat ini, tidak hanya sebatas pada bentuk penghambaan personal, melainkan mengalah pada pembentukan dinamika psikologis. Nyadran melahirkan respon emosional positif, sikap dan perilaku motivasional dan inspiratif. Motivasi untuk hidup dalam kedamaian, ketentraman, keunggulan, dan kesejahteraan. Selalu bersemangat dan memiliki inspirasi dalam menjunjung tinggi nilai-nilai tradisi nyadran dalam kehidupan. Implikasi sosiologis dari ritual nyadran adalah bentuk hubungan yang harmonis, solidarits sosial yang ditunjukkan ahli waris kepada nenek moyangnya dalam konsep birul wa lidain, keikutsertaan seluruh generasi keluarga (baik generasi tua maupun keluarga muda), proses interaksi sosial yang harmonis sebagai bentuk akomodasi budaya lintas agama.

\section{Bibliography}

Abdullah, Taufiq, dan Abdurrachman Suryomihardjo, 1985, Ilmu Sejarah dan Histografi: Arah dan Perspektif, Jakarta: Gramedia.

Ahmadi, Abu, 1989, Psikologi Sosial, Jakarta: Rieneka Cipta. 
Ankersmit, F.R., 1987, Refleksi tentang Sejarah, (terj.) Dik Hartoko, Jakarta: Gramedia.

Bakker, Anton, dan Achmad Charris Zubair, 1990, "Filsafat Sejarah", Diktat, dalam Metodologi Penelitian Filsafat, Yogyakarta: Kanisius, dalam https://books. google.co.id/books?id=CyU8Ai2ijc0C\&pg=PA7\&hl=id\&source=gbs_selected_ pages\&cad=2\#v=onepage\&q\&f=false, diakses 12 Mei 2015.

Collingwood, R.G., 1956, The Ideas of History, New York: A Galaxy Book.

Daliman, 2014, Pengantar Filsafat Sejarah, Yogyakarta: PT. Ombak Dua.

Departemen Pendidikan dan Kebudayaan, 1985, Teori dan filsafat Sejarah, Jakarta: Dikti.

Dhavamony, Mariasusai, 1995, Fenomenologi Agama, Yogyakarta: Kanisius.

Document of The World Bank, LN. 2543 - IND, Report No. 5436a - IND, Staff Appraisal Report Kedung Ombo Multipurpose Dam and Irrigation Project, 24 April 1985.

Dokumen Pemerintah Kabupaten Boyolali, 2011, Data Monografi Kec. Kemus Kabupaten Boyolali.

Effendi, Onong Uchjana, 2009, Komunikasi Teori dan Praktek, Bandung: PT. Remaja Rosda Karya.

Faizah, dkk., 2001, Psikologi Dakwah, Jakarta: Prenada Media.

Ghazalba, Sidi, 1986, Pengantar Kebudayaan Sebagai Ilmu, Yogyakarta: Pustaka Antara.

Hadi, dan Muryati, 2013, Pelestarian Budaya Nasional Melalui Kegiatan Tradisional Nyadran, Majalah Ilmiah Pawiyatan, Volume XX, Nomor 3, Agustus 2013, hlm. 100-113.

Handayani, 1995, Fungsi Upacara Tradisional Bagi Masyarakat Pendukungnya Masa Kini. Jakarta: Depdikbud.

Harian Kompas, tanggal 6 Maret 1989.

Hasanah, Hasyim, 2013, Dimensi Spiritual, Sosial, dan Psikologis Tradisi Nyadran, Makalah (tidak dipublikasikan), Fakultas Dakwah IAIN Walisongo.

Hasanah, Hasyim, Menakar Implikasi Psiko-sosio-religius Perayaan Imlek Etnis Thionghoa Lasem Rembang, Jurnal Penelitian Islam Empirik, STAIN Kudus, Volume 6, Nomor 1, Januari-Juni 2013, hlm. 88-106.

Hatta, H. Mohammad, 2002, Ganti Rugi Pembebasan Tanah Untuk Kepentingan Proyek Pemerintah (Studi Kasus Proyek Irigasi Kedung Ombo Jawa Tengah), Tesis, (tidak dipublikasikan), Universitas Diponegoro.

Istiqomah, Nurul, 2013, Kerukunan Antar Umat Beragama Dalam Ritual Nyadran di Sorowajan Banguntapan Bantul Yogyakarta, Skripsi, UIN Sunan Kalijaga Yogyakarta.

Jamil, Mukhsin, 2012, Multikulturalisme dalam Perspektif Agama dan Kepercayaan (Menimbang 
Islam Kultural), Makalah, Seminar Nasional Pelaksanaan Multikulturalisme Dalam Pembangunan Kebudayaan dan Pariwisata, Kementerian Kebudayaan dan Pariwisata RI.

Karmono, 2005, Pelasanaan Pemberian Ganti Rugi Dalam Rangka Pengadaan Tanah Untuk Proyek Pembangunan Waduk Kedung Ombo Di Wilayah Kabupaten Boyolali, Tesis, (tidak dipublikasikan), Universitas Diponegoro.

Koentjoroningrat, 1980, Kebudayaan Jawa, Jakarta: PN. Balai Pustaka.

Machievelli, dalam Anton Bakker, 2011, "Filsafat-Metodologi Penelitian”, Buku Ajar, Reza Wattimena (ed.), Yogyakarta: UGM.

Mahmudi, Ahmad, 2015, "Proses pemberdayaan masyarakat Kemusu pasca bencana kelaparan tahun 1985-1990", Power Point, Workshoop Pemberdayaan Masyarakat Partisipatori, LP2M UIN Walisongo.

Maritain, Meerhoff, 2005, The Philosophy of History in Our Time, (terj.), New York: Anchor.

Ni'mah, Annisaul Dzikrun, Dwi Sulistyorini, dan Musthofa Kamal, tt., Makna Simbol Ritual Sesaji, Makalah, Universitas Negeri Malang.

Nurmalitasari, 2012, "Makna dan Objek Tradisi-Jawa", dalam http://Nurmalitasari.blog.com/ Makna-dan-Objek-Tradisi-Jawa-html, diakses 25 April 2015.

Permadi, 2005, "Makna Tombak dan Keris bagi Masyarakat Jawa” dalam http://indokerisgallery. blogspot.com/2013/01/makna-keris-menurut-budaya-jawa.html, diakses 20 Mei 2015).

Prasetyo, Yanu Endar, 2010, Mengenal Tradisi Bangsa, Yogyakarta: PT. Insist Press.

Purwadi, 2006, Jejak Para Wali Ziarah Spiritual, Jakarta: Kompas Media.

Purwadi, 2009, Sejarah Walisongo, Yogyakarta: Ragam Media.

Ranjabar, Jacobus, 2006, Sistem Sosial Budaya Indonesia Suatu Pengantar, Bogor: Ghalia Indonesia.

Ritter, Harry, 1986, Dictionary of Concept in History in Our Time, Newyork: Greenwood Press.

Riyadi, Agus, 2015, Akomodasi Kearifan Lokal Dalam Bingkai Lintas Agama (Studi Kasus Tradisi Nyadran yang diselenggarakan Lintas Agama di Desa Kayen Kecamatan Juwangi Kabupaten Boyolali), Proposal Penelitian, LP2M UIN Walisongo.

Rohman, Mujibur, "Nyadran” dalam http://MujiburRohman.Blogspot.com/2010/06/NyadranAgung-JogjaTrip-html, diakses 25 April 2015.

Stanley, Adi Prasetya, 1994, Seputar Kedung Ombo, Jakarta: ELSAM.

Suyitno, Widiyanto Tri, 2001, Jalan Membebaskan Leluhur dari Alam Menderita, Yogyakarta: Vihara Karangjati. 
Van Laer, Henry, 1962, Philosophy of Science, Part 2: A Studi of The Devision and Nature of the Vorious Grroup of Sciences, USA: Mishawaka Duquesne University Press.

Walsh, W.H., 1977, An Introduction to Phylosophy of History, London: Hutchinson.

Widjaja, A.W., 1993, Komunikasi Dan Hubungan Masyarakat, Jakarta: Bumi Aksara.

Wilujeng, Sri Rahayu, 2012, Filsafat, Etika, dan Ilmu (Upaya Memahami Hakikat Ilmu dalam Kontes Keindonesiaan), Jentra, Fakultas Ilmu Budaya Universitas Diponegoro, Volume 3, Nomor 2, Oktober 2012. 
